\title{
Beryllium-Uranium System
}

\author{
R. W. Buzzard
}

\begin{abstract}
The phase diagram of the system beryllium-uranium was constructed from data obtained by thermal analysis, metallographic examination and X-ray diffraction. The system is characterized by one intermetallic compound, $\mathrm{UBe}_{13}$, melting at about $2,000^{\circ} \mathrm{C}$, a eutectic having a composition of approximately 0.12 weight percent of beryllium, occurring between uranium and $\mathrm{UBe}_{13}$, at $1,090^{\circ} \mathrm{C}$, and a monotectic occurring at $1,550^{\circ} \mathrm{C}$ and 60 -weightpercent of beryllium. The solid solubility of beryllium in uranium is slight; no solid solubility of uranium in beryllium was detected. The transformation temperatures of uranium are not affected by additions of beryllium.
\end{abstract}

\section{Introduction}

The literature contains very little data on the beryllium-uranium system. This lack of information can be ascribed to the technical difficulties resulting from the high vapor pressure of beryllium and the large difference in the densities of the two components. A tentative phase diagram of the berylliumuranium system was presented in the literature review by Buzzard and Cleaves. ${ }^{2}$ The diagram shows one compound, approximating $\mathrm{UBe}_{9}$ in composition and two eutectics, one at $1,060^{\circ} \mathrm{C}$ between gamma uranium and $\mathrm{UBe}_{9}$, and the other at $1,200^{\circ}$ to $1,250^{\circ}$ $\mathrm{C}$ between beryllium and $\mathrm{U} \mathrm{Be}_{9}$.

In order to have available a more accurate diagram of the beryllium-uranium system, work was initiated at the National Bureau of Standards at the request of the Atomic Energy Commission. A series of beryllium-uranium alloys was prepared with compositions ranging from 0 - to 100 -percent beryllium and analyzed metallographically, by X-ray diffraction, and by thermal analysis.

\section{Preparation of Alloys}

\subsection{Stock materials, apparatus, and procedures}

The stock materials consisting of extruded beryllium and uranium were obtained from the Atomic Energy Commission. The alloys were prepared in a specially constructed, high-frequency induction furnace, in which the charges could be melted and the ingots poured in an atmosphere of purified helium. This was accomplished by enclosing the beryllia crucible and mold assemblies in a silica tube and by using bottom-pour crucibles. Details of the construction are shown schematically in figure 1 . It is important that the beryllia be fired at approximately $1,900^{\circ} \mathrm{C}$ and be of high purity. The pouring temperatures were determined by sighting through the "sight" tube on the bottom of the stopper with an optical pyrometer. The stopper was essentially a closed end beryllia tube.

${ }^{1}$ Investigation sponsored by the Atomic Energy Commission at the National Bureau of Standards.

${ }^{2}$ R. W. Buzzard and H. E. Cleaves; Issue No. 1, p. 26-27, Journal Metallurgy and Ceramics (TID 65), July 1948.

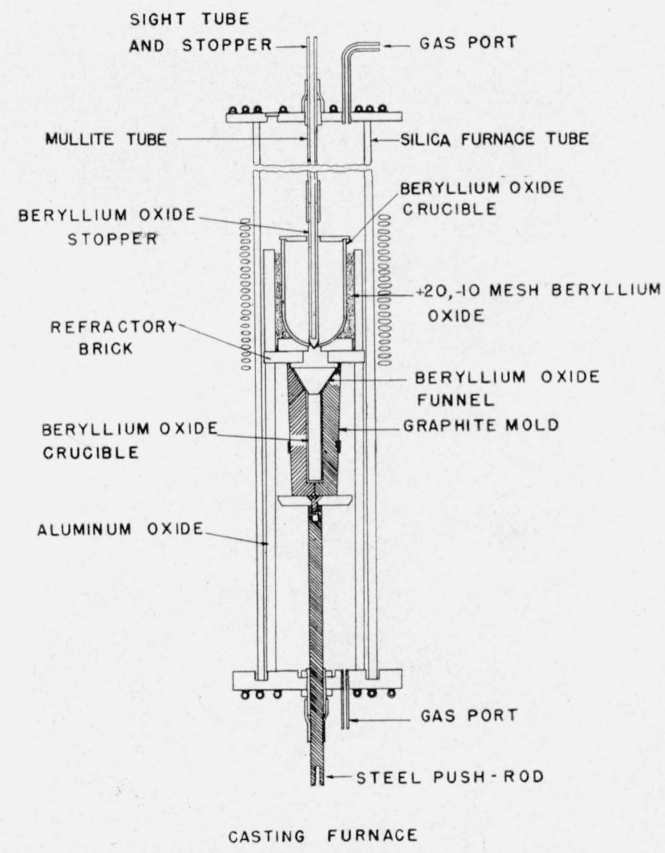

Figure 1. Controlled atmosphere, high frequency induction furnace.

\subsection{Segregation}

The density of the beryllium-uranium compound was considerably greater than the beryllium-rich liquid phase, thereby creating a tendency for the compound to collect at the bottom of the crucible or mold as it precipitated from the cooling liquid. This settling-out tendency was not so pronounced in the uranium-rich phase. It was possible to prepare beryllium-rich alloys reasonably free of segregation by pouring the ingots with the power on full into a cold mold of small cross section. The large supply of power, immediately before pouring, caused a vigorous stirring action, which kept the compound uniformly distributed.

The distribution of uranium in the ingots in the "as cast condition" was checked both by chemical analysis (table 1) and microradiographic examination (figs. 2 and 3). Chemical analysis of the ingots 


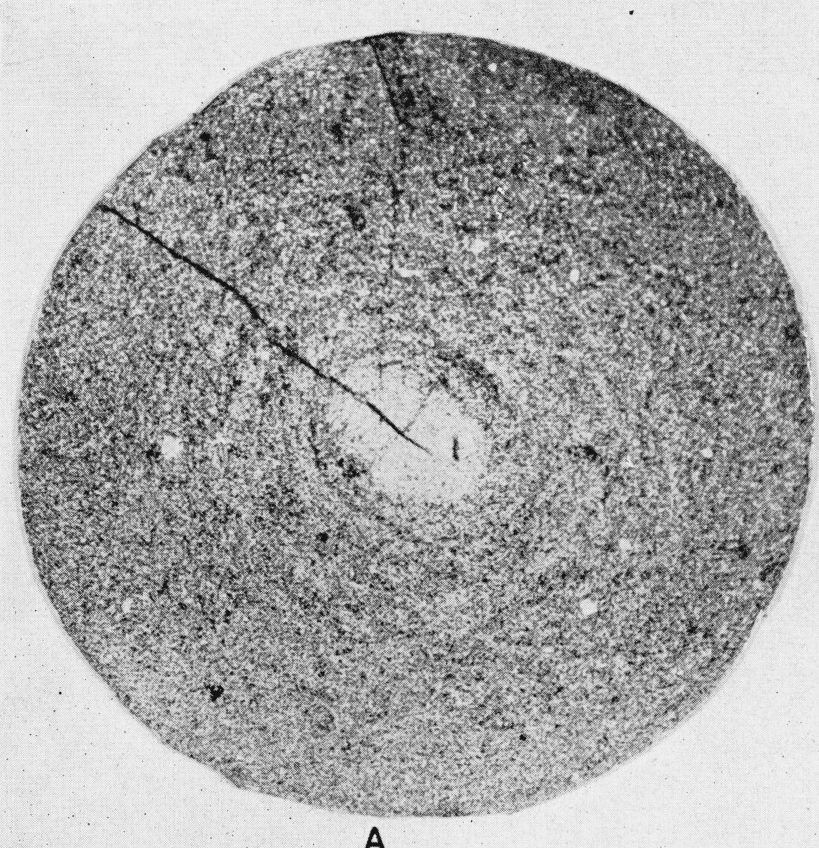

A

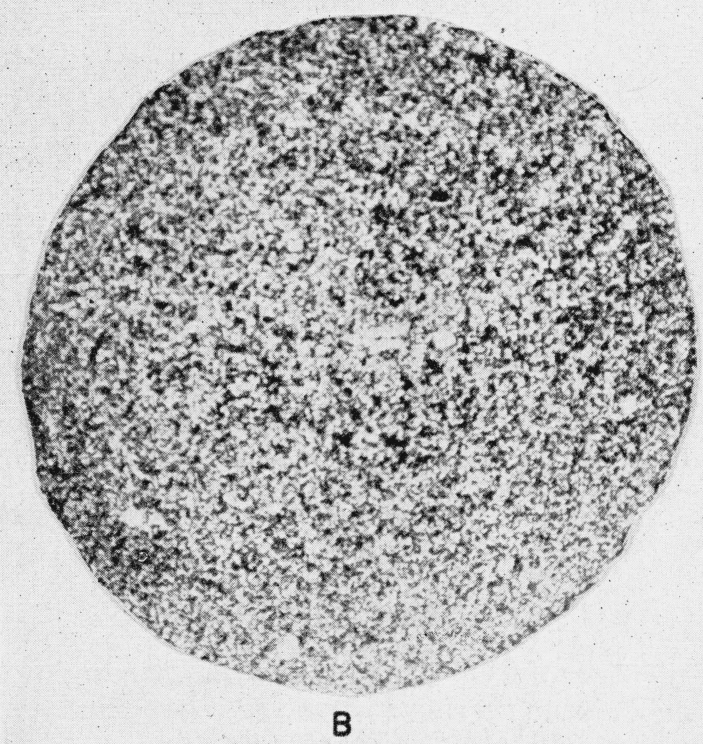

showed satisfactory uniformity of composition from top to bottom, with the exception that the ingot in the 50-weight-percent range had a deviation of 5 percent over its length. The variation from top to bottom in the other ingots was within 1 percent, and the ingots having compositions in the high-uranium and high-beryllium fields showed little deviation in composition from top to bottom. The microradiographs showed good distribution of the compound in the beryllium-rich ingots, with the exception of the 99-weight-percent beryllium ingot. The swirl distribution of the compound shown in the photomicroradiograph (fig. 2, A) is caused by the pouring action and is apparent in this ingot because of the low concentration of the compound.

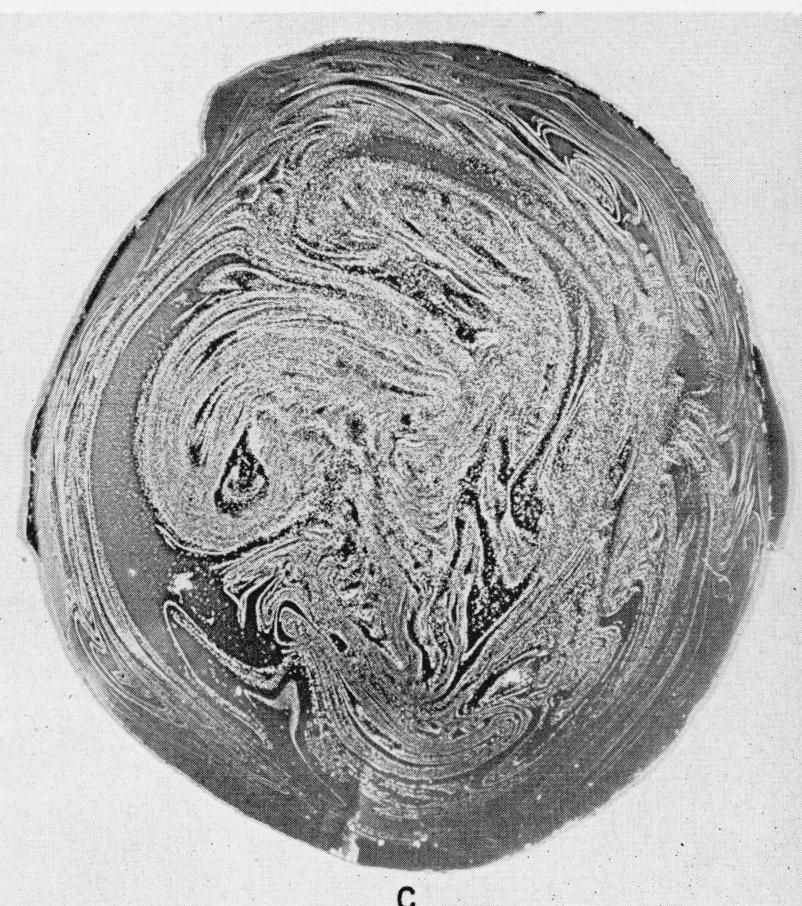

FigURE 2. Photomicroradiographs of horizontal sections of beryllium-rich ingots in the "as cast condition".

The light and dark areas indicate $\mathrm{UBe}_{13}$ and beryllium matrix, respectively; A 99-weight-percent; B, 91.7-weight-percent; C, 824-weight-percent beryllium The photomicroradiographs were obtained with unfiltered cobalt radiation, 4 kvp at a target-to-specimen distance of $28 \mathrm{~cm}$ and photographed at $\times 6 \mathrm{magni}$ fication.

TABLE 1. Composition of cast alloys

\begin{tabular}{|c|c|c|c|c|c|}
\hline \multirow{2}{*}{$\begin{array}{l}\text { Alloy des- } \\
\text { ignation }\end{array}$} & \multirow{2}{*}{$\begin{array}{c}\text { Charge } \\
\text { analysis } \\
\text { of U }\end{array}$} & \multicolumn{2}{|c|}{$\begin{array}{c}\text { Chemical analysis } \\
\text { of } U\end{array}$} & \multirow{2}{*}{$\begin{array}{l}\text { Casting } \\
\text { temper- } \\
\text { ature }\end{array}$} & \multirow{2}{*}{ Remarks } \\
\hline & & Top & Bottom & & \\
\hline & $w t-\%$ & $w t-\%$ & $w t-\%$ & ${ }^{\circ} \mathrm{C}$ & \multirow{19}{*}{$\begin{array}{l}\text { Did not pour at } \\
1,950^{\circ} \mathrm{C} \text {. } \\
1,900^{\circ} \mathrm{C} \text { too low for } \\
\text { good easting. }\end{array}$} \\
\hline $22 \mathrm{~B}$ & 0.2 & 0.16 & (). 17 & 1,500 & \\
\hline $21 \mathrm{~B}$ & 0.5 & & 0.51 & 1,400 & \\
\hline $1 \mathrm{~B}$ & 5. 5 & 5. 90 & 5. 94 & h 1,500 & \\
\hline $2 \mathrm{~B}$ & 10. 2 & 10.53 & 11. 23 & 1,400 & \\
\hline $3 \mathrm{~B}$ & 14.8 & 14.94 & 15. 34 & $\begin{array}{l}1,400 \\
\end{array}$ & \\
\hline $16 \mathrm{~B}$ & 19. 0 & 19.45 & 20.25 & h 1,425 & \\
\hline $5 \mathrm{~B}$ & 30.0 & 30.50 & 30.17 & 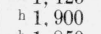 & \\
\hline $6 \mathrm{~B}$ & 40.0 & 43. 05 & 42. 29 & h 1,850 & \\
\hline $7 \mathrm{~B}$ & 50.0 & 44.02 & 49. 68 & h 1,910 & \\
\hline $8 \mathrm{~B}$ & 65.0 & 64.56 & 65. 21 & h 2,020 & \\
\hline 17B & 73.5 & $\begin{array}{l}73.06 \\
76.43\end{array}$ & $\begin{array}{l}73.86 \\
75.9\end{array}$ & h 2.000 & \\
\hline & & 76.43 & & n 1,900 & \\
\hline $\begin{array}{l}18 \mathrm{~B} \\
15\end{array}$ & $\begin{array}{l}77.0 \\
85.0\end{array}$ & $\begin{array}{l}77.54 \\
85.22\end{array}$ & $\begin{array}{l}7 f .70 \\
85.32\end{array}$ & $\begin{array}{l}\text { h } 2,030 \\
\text { h } 1,920\end{array}$ & \\
\hline $10 \mathrm{~B}$ & 95.0 & $\begin{cases}\text { a } & 94.85 \\
\text { b } & 94.07\end{cases}$ & $\begin{array}{l}\text { a } 94.57 \\
\text { b } 93.70\end{array}$ & \} h 1,925 & \\
\hline $11 \mathrm{~B}$ & 99.0 & $\begin{cases}\text { a } & 98.72 \\
\text { b } & 98.70\end{cases}$ & $\begin{array}{l}\text { a } 99.22 \\
\text { b } 98.60\end{array}$ & \}$_{\text {n }} 1,650$ & \\
\hline $12 \mathrm{~B}$ & 99.8 & 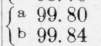 & $\begin{array}{l}\text { a } 99.63 \\
\text { b } 99.82\end{array}$ & 1,400 & \\
\hline 14B & 99.95 & $\begin{cases}\text { a } & 99.85 \\
\text { b } & 99.91\end{cases}$ & $\begin{array}{r}\text { a } 99.80 \\
\text { b } 99.91\end{array}$ & 1,400 & \\
\hline $13 \mathrm{~B}$ & & $\left\{\begin{array}{l}\text { a } 99.89 \\
\text { b } 99.94\end{array}\right.$ & $\begin{array}{l}\text { a } 99.85 \\
\text { b } 99.93\end{array}$ & \} 1,410 & \\
\hline
\end{tabular}

a W et chemical analysis for $\mathrm{U}$. $\mathrm{h}$ Graphite heater around crucible. b Spectrographic analysis of $\mathrm{Be}, \mathrm{U}$ by difference. 

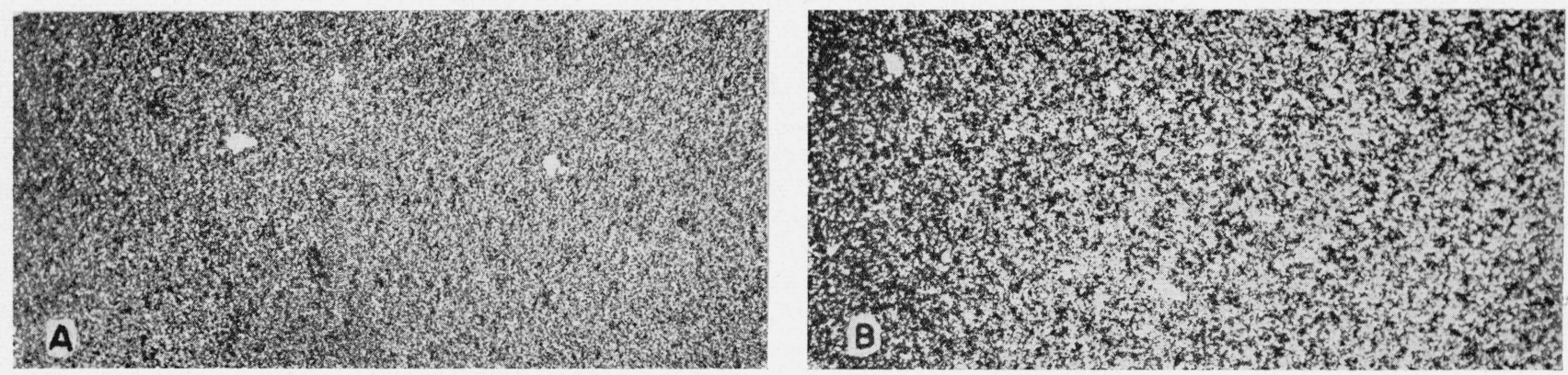

Figure 3. Photomicroradiographs of vertical sections of beryllium-rich ingots in the "as cast condition".

A, 82.4-weight-percent and B, 91.7-weight-percent beryllium $\times 6$ magnification.

\section{Thermal-Analysis Apparatus and Procedure}

The solid-phase arrests were determined by timetemperature analysis, using a modification of the apparatus described by Teitel and Cohen. ${ }^{3}$ The accessory apparatus included a Brown Air-o-line program controller to maintain uniform heating and cooling rates. A furnace atmosphere of purified argon was used in order to minimize the evaporation of beryllium. Arrests with this equipment could be determined with an accuracy of $\pm 2 \mathrm{deg}$ C.

For regions involving a liquid phase, the highfrequency induction furnace used to prepare the cast alloys was modified for thermal analysis by substituting a tapered crucible for the bottom-pour-casting crucible. A beryllia plug was inserted in the stopper tube to a height such that temperature observations were made at the center of the melt, using a high precision optical pyrometer. The cooling rates were controlled by manually reducing the power of the convertor at a uniform rate in a manner that cooling rates of the order 0.5 to $2.0 \mathrm{deg} / \mathrm{min}$ were obtained through the thermal arrests. The solidus and solidphase arrests of the beryllium-rich alloys were determined in this furnace, using platinum-rhodium thermocouples enclosed in high-fired-alumina protection tubes and inserted through the sight tubes. The tip of the couple was seated on the top of the beryllia plug. The convertor control was modified so that the power could be reduced mechanically with an electric motor operating through a gear box. The time-temperature curves were recorded on a Brown electronic recorder.

\section{Results}

\subsection{Beryllium-uranium compound}

Metallographic examination showed all of the cast alloys (table 1) to consist of two phases. One phase increased in amount from either the uranium or beryllium end of the system until at approximately 35-weight-percent beryllium, the alloy appeared to be composed almost entirely of this phase (fig. 4, E, F). Alloys in this range were hard and very brittle.

3 R. J. Teitel and |Morris Cohen, Trans. Am. Inst. Mining Met. Engrs. 185 $285-296(1949)$.
It was found that this phase could be readily isolated from a uranium matrix by electrolytically dissolving the uranium in a 10-percent chromicacid solution. The separated phase was identified as the intermetallic compound $\mathrm{UBe}_{13}$ having a cubic structure, as reported by Baenziger and Rundle. ${ }^{4}$ Precision determination of the lattice constant gave a value of $a=2 \times 5.1849 . \pm 0.0001 \AA$ at $27^{\circ} \mathrm{C}$.

In order to check the stoichiometric formula, $\mathrm{UBe}_{13}$, a density determination and chemical analysis were made. The values obtained were $4.420 \pm 0.002$ $\mathrm{g} / \mathrm{cm}^{3}$ at $26^{\circ} \mathrm{C}$ and $32.15 \pm 0.05$-weight-percent beryllium as compared to the computed values of $4.373 \mathrm{~g} / \mathrm{cm}^{3}$ and 33.0-weight-percent beryllium. The actual and computed values are in sufficient agreement to conclude that the formula is $\mathrm{UBe}_{13}$ and not $\mathrm{UBe}_{9}$ as previously reported. The thermal-analysis results indicate that the melting point of $\mathrm{UBe}_{13}$ was approximately $2,000^{\circ} \mathrm{C}$.

\subsection{Beryllium-rich alloys}

Data (table 2) from the time-temperature cooling curves obtained for the beryllium-rich alloys show a monotectic at 60-weight-percent beryllium and $1,550^{\circ} \mathrm{C}$ (fig. 5). The liquidus and liquid solubility temperatures above $1,600^{\circ} \mathrm{C}$ were influenced by the vapor phase of the beryllium, and the accuracy is not greater than $\pm 25 \mathrm{deg} C$. The maximum temperature indicated for the $\mathrm{UBe}_{13}$ composition is a selected value based on an evaluation of the thermal data, casting temperatures, and extrapolation of the liquidus curve. The solidus $\left(1,280^{\circ} \mathrm{C} \pm 3^{\circ}\right)$ coincided with the melting point of beryllium at $1,283^{\circ}$ C. A pronounced arrest occurred below the solidus at $1,250^{\circ} \mathrm{C} \pm 10^{\circ}$, which can be ascribed either to impurities or an allotropic transformation in the beryllium phase, although the strong arrests observed at this point indicate a possibility of the latter. Previous investigators ${ }^{2,5,6,7}$ have observed similar double points in the melting-point determinations of beryllium and have concluded impurities to be the cause, but lacking conclusive proof as to the cause of the observed double arrest, the line is dotted on the diagram.

\footnotetext{
4 N. C. Baenziger and R. E. Rundle, United States Atomic Energy Com mission. AECD-2506 (A pril 8, 1949 )

5 G. Oesterheld, Z. anorg. 11 allgem. Chem. 97 1-6 (1916).

6 L. Losano, Alluminio 867 (1939)

H. A. Sloman, J. Inst. Metals 49365 (1932)
} 

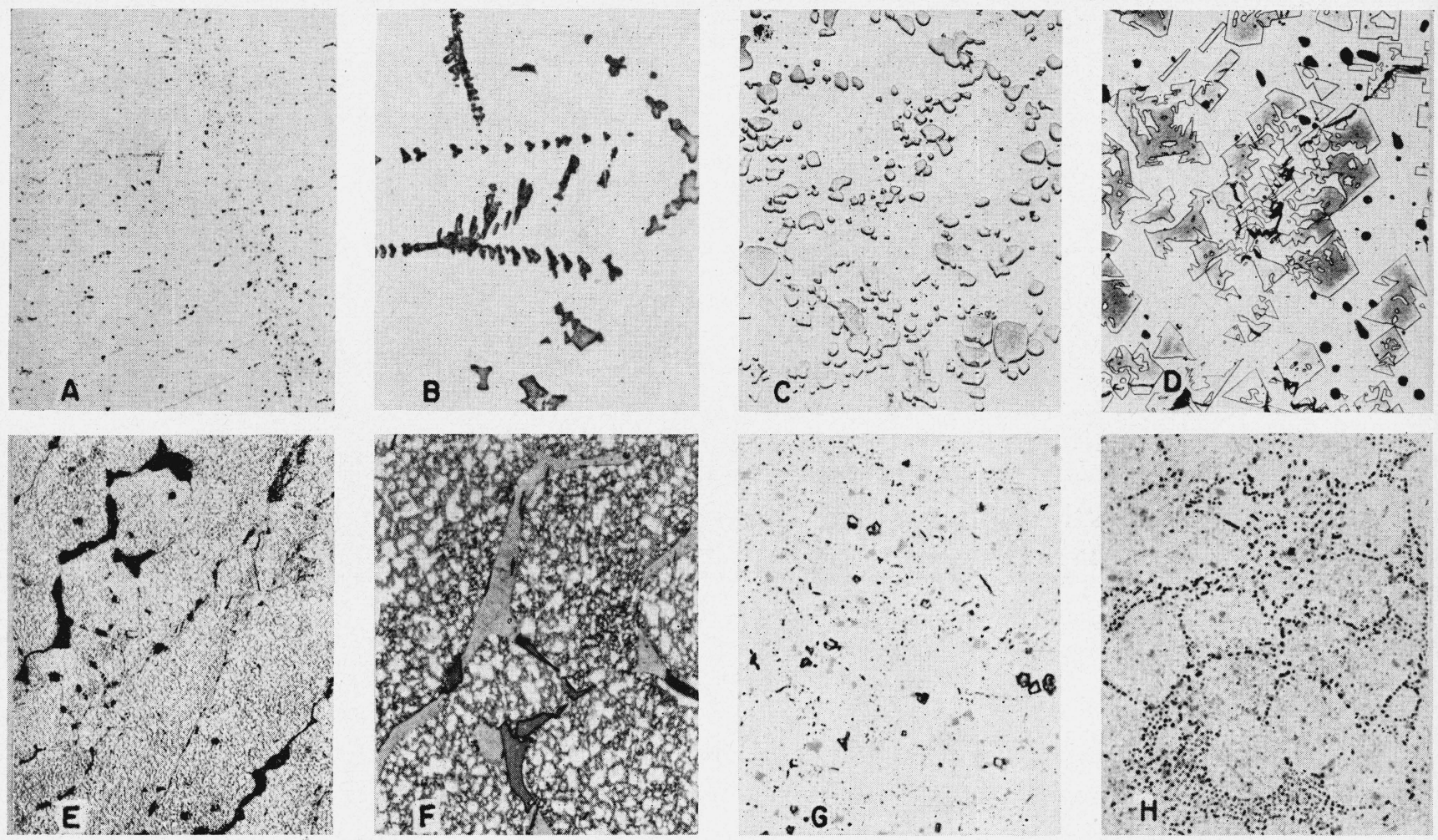

FiguRE 4

Typical microstructures of beryllium-uranium alloys in the "as cast condition".

Etchant 5 percent HF, A, B, C, D, E, G, and $\mathrm{H}$ at $\times 100$, F at $\times 500$. A, 99.49-weight-percent beryllium; B, 98.86-weight-percent beryllium; C, 80.15-weight-per cent beryllium; D, 69.7-weight-percent beryllium, dark constituent, $\mathrm{UBe}_{13}$, in light matrix of beryllium; $\mathrm{E}$ and $\mathrm{F}$, 35.1-weight-percent beryllium, dark areas at low magnification are shown at high magnification to be beryllium (pale grev) and the mottled background is UBe13: $G$, 0.17 -weight-percent beryllium, small angular areas, sharply outlined, are UBe13 particles; $\mathrm{H}, 0.09$-weight-percent beryllium. The uranium-UBe13 eutectic is shown in an uranium matrix.

TABLE 2. Summary of thermal data obtained for beryllium-rich

alloys

\begin{tabular}{|c|c|c|c|c|c|}
\hline \multirow{2}{*}{$\mathrm{Be}$} & \multicolumn{5}{|c|}{ Thermal arrests a } \\
\hline & $\begin{array}{c}\text { Miscibility } \\
\text { of } \mathbf{L}_{1}+\mathbf{L}_{2}\end{array}$ & Liquidus & $\mathrm{L}_{1}+\delta \rightarrow \mathrm{L}_{2}+\delta$ & Solidus & $\epsilon+\delta \rightarrow \eta+\delta$ \\
\hline$w t-\%$ & ${ }^{\circ} \mathrm{C}$ & ${ }^{\circ} \mathrm{C}$ & ${ }^{\circ} \mathrm{C}$ & ${ }^{\circ} \mathrm{C}$ & ${ }^{\circ} \mathrm{C}$ \\
\hline 100 & - & $\left\{\begin{aligned} \text { b } 1,282 \\
1,283\end{aligned}\right.$ & & - & b 1,263 \\
\hline 99.5 & & $\left\{\begin{array}{r}\text { b } 1,283 \\
1,286\end{array}\right.$ & & - & b 1,264 \\
\hline $\begin{array}{l}99.0 \\
98.5\end{array}$ & - & $\begin{array}{r}1,280 \\
\text { ' } 1,284 \\
1,289\end{array}$ & & (n) & c 1,233 \\
\hline $\begin{array}{l}98.0 \\
96.5\end{array}$ & - & $\begin{array}{l}1,286 \\
1,294\end{array}$ & & $\begin{array}{l}1,282 \\
1,283\end{array}$ & $\begin{array}{l}1,223 \\
1,234\end{array}$ \\
\hline 95.0 & - & 1,289 & & $\left\{\begin{array}{l}\text { c } 1,281 \\
1,200\end{array}\right.$ & c 1,241 \\
\hline 93.5 & - & 1,285 & - & ( $\quad 1,283$ & 1,228 \\
\hline 92.5 & (- & 1, 299 & & 1,282 & - \\
\hline 91.0 & ........ & 1,297 & .... & 1,271 & \\
\hline 90.0 & - & 1,303 & - & $\left\{\begin{array}{r}{ }^{\circ} 1,280 \\
1,284\end{array}\right.$ & $\begin{array}{r}{ }^{\circ} 1,238 \\
1,239\end{array}$ \\
\hline 87.5 & -........ & 1. 399 & & & \\
\hline $\begin{array}{l}85.0 \\
82.5\end{array}$ & - & $\begin{array}{l}1,399 \\
1,548\end{array}$ & (n....... & c 1,286 & ' 1,240 \\
\hline 80.0 & 1,588 & 1,548 & n & 1,280 & (n....... \\
\hline $\begin{array}{l}77.5 \\
75.0\end{array}$ & $\begin{array}{l}1,682 \\
1,832\end{array}$ & 1. 551 & -........ & -....... & - \\
\hline $\begin{array}{l}75.0 \\
72.5\end{array}$ & $\begin{array}{l}1,832 \\
1,808\end{array}$ & $\begin{array}{l}1,550 \\
1,50\end{array}$ & (n) & (n) & $\circ 1,239$ \\
\hline 70.0 & 1,874 & 1,562 & & - & - \\
\hline $\begin{array}{l}67.5 \\
65.0\end{array}$ & $\begin{array}{l}1,808 \\
1,748\end{array}$ & 1,550 & - & (n)..... & -........ \\
\hline 64.0 & & & & b 1,284 & b 1,267 \\
\hline 61.0 & 1,642 & - & 1,547 & & \\
\hline 60.0 & 1,551 & & 1,550 & ' 1,282 & ' 1,253 \\
\hline 57.5 & & 1,757 & 1,548 & & 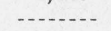 \\
\hline 55.0 & n........ & 1,820 & 1,556 & - & - \\
\hline 50.0 & - & 1,885 & 1,554 & 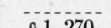 & \\
\hline $\begin{array}{l}45.0 \\
40.0\end{array}$ & - & $\begin{array}{l}1,882 \\
1,843\end{array}$ & 1,552 & ${ }^{\circ} 1,270$ & • 1,237 \\
\hline 35.0 & . & 1,858 & -... & . & .......... \\
\hline
\end{tabular}

all points not otherwise indicated were determined in high-frequency induction furnace, using an optical pyrometer.

b Points determined in resistance furnace.

c Points determined in high-frequeney furnace with

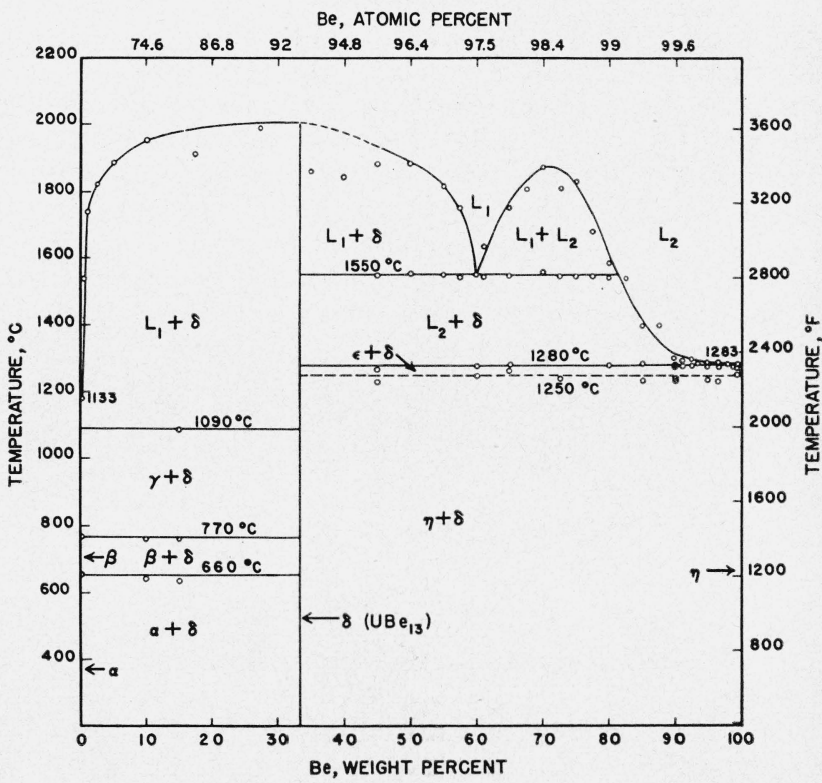

Figure 5. Beryllium-uranium phase diagram. 
Metallographic examination showed that the cast structures of the alloys in the composition range 35 - to 100-weight-percent beryllium consisted of particles of $\mathrm{UBe}_{13}$ embedded in a beryllium matrix. Homogenizing treatments up to $1,225^{\circ} \mathrm{C}$ produced no change in the structures. The compound appeared in an angular form (figs. 4, A, B, D) over the entire composition range, with the exception of a narrow range between $92-$ to 80 -weight-percent beryllium, in which the compound was observed to have a globular form (fig. 4, C). All evidence indicated the solubility of uranium in beryllium was very limited and was not detected in this investigation.

\subsection{Uranium-rich alloys}

The cooling curves (table 3) obtained for the uranium-rich alloys indicate a eutectic at approximately 0.12 -weight-percent beryllium and $1,090^{\circ} \mathrm{C}$. Arrests were obtained at $770^{\circ}$ and $660^{\circ} \mathrm{C}$ that correspond to the two allotropic transformation temperatures, indicating little or no solid solution of beryllium in alpha or beta uranium (fig. 6).

TABLE 3. Summary of thermal data obtained for the uraniumrich alloys

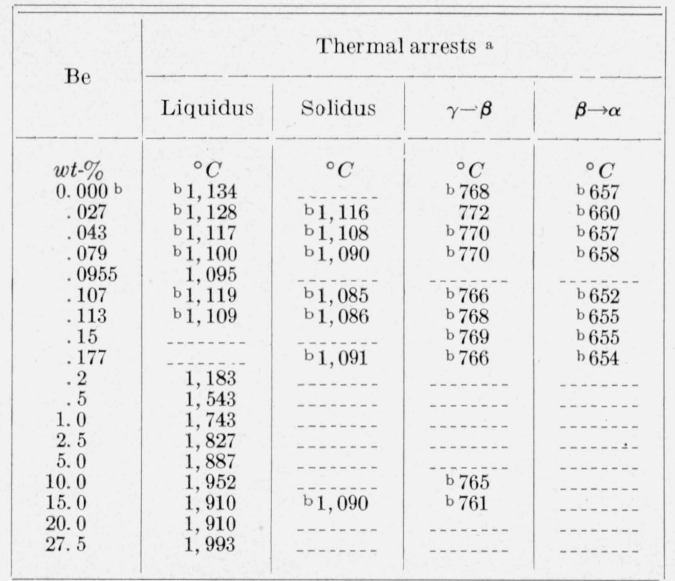

a All points not otherwise indicated were determined in high-frequency induction furnace, using an optica1 pyrometer.

b Points determined in resistance furnace.

Metallographic examination showed that alloys in the vicinity of the uranium-UBe $\mathrm{UB}_{13}$ eutectic, as indicated by thermal analysis, contained a definite eutectic structure (figs. 4, G, H). Homogenization near the solidus spherodized the $\mathrm{U} \mathrm{Be}_{13}$. X-ray analysis of alloys quenched from $1,075^{\circ} \mathrm{C}$ in the range 0.027 to 0.079 -weight-percent beryllium, placed the solid solubility of beryllium in gamma uranium between 0.042 to 0.079 -weight-percent at $1,075^{\circ} \mathrm{C}$.

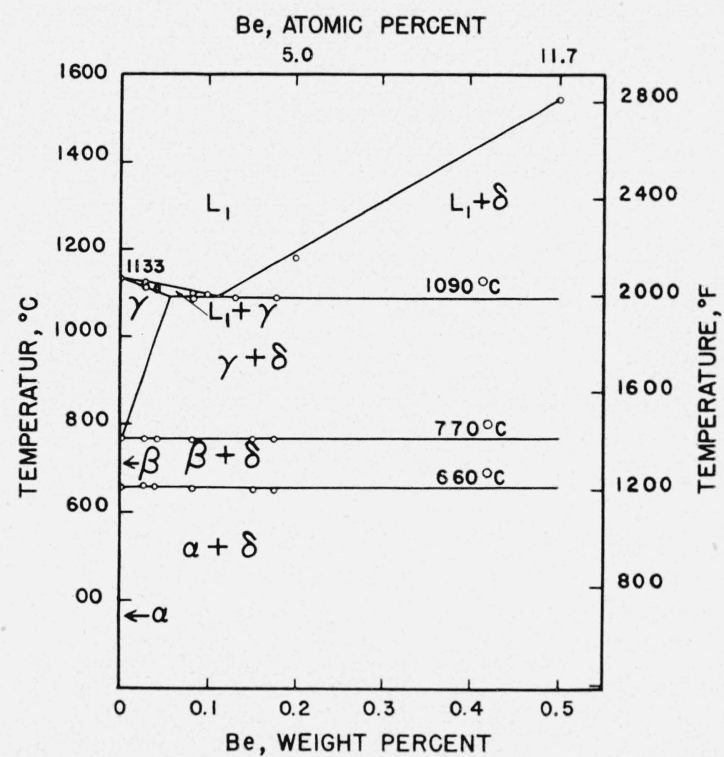

FIGURE 6. Uranium-rich section of beryllium-uranium phase diagram.

\section{Summary}

The phase diagram of beryllium and uranium was constructed from data obtained by thermal analysis, metallographic examination, and X-ray diffraction (figs. 5 and 6). The beryllium-uranium system is characterized by one intermetallic compound, $\mathrm{UBe}_{13}$, having a melting point of approximately $2,000^{\circ} \mathrm{C}$. A eutectic, having a composition of approximately 0.12-weight-percent beryllium, occurs between uranium and $\mathrm{UBe}_{13}$ at $1,090^{\circ} \mathrm{C}$. A monotectic occurs at $1,550^{\circ} \mathrm{C}$ and 60 -weight-percent beryllium.

A slight solubility of beryllium in gamma-uranium is indicated, but no solubility of uranium in beryllium was detected. The transformation temperatures of uranium were unaffected by additions of beryllium.

The author expresses his appreciation to John H. Darr, J. T. Sterling, and S. J. Rosenberg for their assistance in developing the thermal data; to R. A. Lindberg for the preparation of the beryllia refractories; to H. C. Vacher, Ellen A. Buzzard, and Robert Liss for the X-ray and metallographic analysis; to Martha S. Richmond for the chemical analysis; and to Martha M. Darr for the spectrographic analysis.

Washington, October 1, 1952. 